
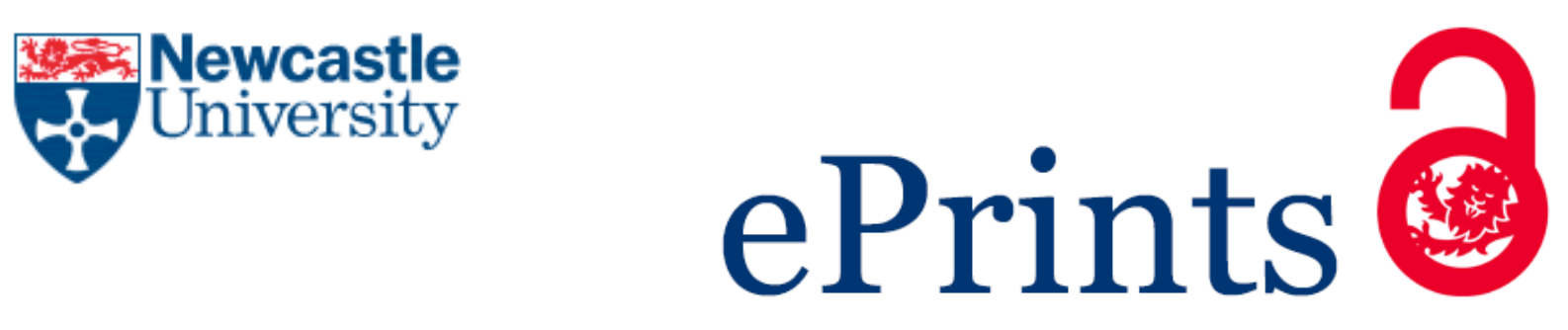

Button CM.

Domesticating water supplies through rainwater harvesting in Mumbai. Gender \& Development 2017, 25(2), 269-282

\title{
Copyright:
}

This is an Accepted Manuscript of an article published by Taylor \& Francis in Gender \& Development on 11/7/2017, available online: http://www.tandfonline.com/10.1080/13552074.2017.1339949

DOI link to article:

http://dx.doi.org/10.1080/13552074.2017.1339949

Date deposited:

$12 / 07 / 2017$

Embargo release date:

11 January 2019

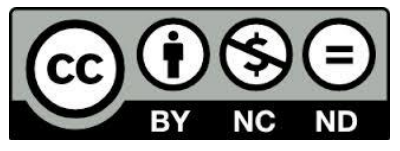

This work is licensed under a

Creative Commons Attribution-NonCommercial-NoDerivatives 4.0 International licence 


\section{Domesticating water supplies through rainwater harvesting in Mumbai}

\section{Cat Button}

Mumbai is a city where 60 per cent of the population are living in poverty in informal settlements, with low - and decreasing - water access, and low resilience to water shortage. In the middle-class areas of the city, inhabitants are being made responsible for securing their own water supplies via rainwater harvesting technology, which is increasingly installed in new housing. This shifts responsibility for water provision from city authorities to private households. The domestication of water supplies could potentially give residents more control, and could also change the gendered power balance of water provision. However, this article argues that making the middle classes responsible for their own water provision in a context of water shortage and environmental concerns has justice implications. People living in poverty are not able to self-provision in this way; yet on the other hand, the move could free up more of the piped water supply. The article draws on three case studies offering different experiences of the impact of the policy, to reflect on concepts of power, gender and environmental justice.

Key words: Water; Infrastructure; Domestic; Mumbai; Governance; rainwater harvesting.

In the city of Mumbai, India, 60 per cent of the population are living in poverty in informal settlements, with low - and decreasing - water access, and low resilience to water shortage (Srivastava and Echanove, 2014)The city authorities have struggled to provide water to residents in the past (Gandy, 2006). In a context of low and decreasing water access and low resilience to water shortages, innovative ways of solving the shortage are needed, and, '[f]or the first time in its history, the city's municipal corporation and its water engineers have been engaged in educational and outreach programmes to encourage changes in household water use and the introduction of water-saving technologies' (Gandy, 2006: 19).

As part of this agenda, the responsibility for securing water resources in Mumbai's middle-class households has been shifted onto the residents themselves, via rainwater-harvesting technologies installed for individual households. In Mumbai's domestic properties, decentralised water provision by the general population of an area (from bore-wells and tankers) is being extended or replaced by rainwater harvesting. This means that more water is being supplied at the level of an individual building, and therefore housing is becoming a site of production, not just consumption. This blurring of the boundaries between supplier and consumer, and between housing and infrastructure, has implications for the governance of infrastructure and distribution of power (see Bakker, 2010).

The case studies featured here are the result of fieldwork during two extended periods in Mumbai (between 2009 and 2011), and several subsequent trips to India. Each of the three focuses on rainwater harvesting systems and how they are used. The first concerns a middle-class apartment building that was an early adopter of environmental decentralised infrastructure; the second is another apartment building with rainwater harvesting where residents reflect on the experiences of the female maids who work there but live in an informal settlement; and the third is a slum that has a rainwater harvesting system for a toilet block.

In this study, I was keen to include a variety of methods such as using photographs, walking interviews during visits to buildings, and ethnographic observations. I developed photographic methodologies around these visits, which were particularly useful to the investigations. This included in-depth site visits to 22 apartment buildings in north Mumbai, and one informal settlement. 
The focus on the middle classes and professionals brought interviews to prominence as a key method to collect data to address all research questions. Interviews of individuals or small groups lasted between 15 minutes and 2 hours, with an average of about half an hour. Most of those interviewed were professionals or experts (architects, consultants, property developers, NGO officers, government officials etc.: 24 male and 9 female) in their own offices Mumbai. I also interviewed residents (7 male and 9 female) and servants ( 1 male and 2 female). I interviewed one watchman (Mumbai 12/02/2011) and two maids (Mumbai 08/02/2011). The watchman gave me insights into how the building had changed over the past decade and the maids explained some of the everyday practices they undertook.

Employers were often unwilling to let me speak to servants because they did not consider the servants' knowledge important. One building secretary couldn't grasp (after a year of explaining) why I would want to talk to staff when he could explain everything and he thought watchman wouldn't know anything (interviews, Mumbai 2009-2011). I repeatedly met with this rhetoric of servants not knowing anything and their input to my research not being needed. This dismissal of needing to speak to other people also brought out the power dynamics of knowledge and justice issues arising from assumed superiority of some respondents. I was keen to speak to servants who used water that was harvested, so that I could understand exactly what they did, whether practices had changed since installation and what their knowledge of the systems was. However, there were language barriers in speaking to them leaving me with no option but to use a 'gatekeeper' who was often also their employer as translator. This compromised results as servants might have adapted their answers to please their employers. It also meant that I was not hearing their 'true voice' and something may be altered or omitted in translation. I was also able to use my observations from site visits and ethnographic methods to investigate these everyday practices. My primary data is also supported by policy and media sources, and attending conferences was also a useful way to gain an insight into official standpoints of organisations and government departments

This article begins with an introduction to Mumbai's water supplies, followed by a discussion of rainwater harvesting as a technology. I then move on to focus on domestication, a concept that I used to gain a rounded understanding of the impact and implications of rainwater harvesting for environmental sustainability, the satisfaction of WASH needs, and power relations: between individual households and the city governance, between middle-class and poorer residents of Jaipur, and between women and men. The three case studies are then analysed. Issues of power and justice are drawn out in the discussion, and this leads to conclusions and recommendations.

\section{Mumbai's water infrastructure}

Water infrastructure is highly differentiated and uneven across Mumbai. The Municipal Corporation of Greater Mumbai (MCGM, also known as BMC) still bears the sole responsibility for water supply in the city (BrihanMumbai Municipal Corporation, 2003). However in reality the municipality is just one of the actors in a system of governing (Bulkeley and Betsill, 2003). This is evident in the provision of tankers by private enterprises and the 'water mafia' to fill demand. The MCGM acknowledges that there is a shortfall in this supply, and this has led the municipality to implement water-saving tactics, and to shift responsibility. This is instead of other routes such as investing on the current system to remove leakages or selling of the (lucrative) water utility for privatisation.

It is expected that there should be an active participation of the citizens in water conservation (saving). Citizens have to generate water for secondary requirements through rain water harvesting or recycling.

(Municpal Corporation of Greater Mumbai (MCGM), 2008: 1). 
This approach to water-saving in the city of Mumbai might be seen as a positive move, but it is more complex than that. Underlying it is an attempt by the government to roll-back its responsibility for water provision. The splintered provision of water in Mumbai has roots in the colonial planning of the city (Zérah, 2008). The water department was created in 1860 to supply water from lakes when the existing wells and tanks were insufficient, due to drought and urbanisation, and yet the colonial government did not have aspirations that mains water would be universally provided (Anand, 2011). Although the network of supply pipes has been extended, it has not kept up with urban growth, and a shortage of water supply has been created.

Mains drinking water comes from several reservoirs or lakes outside the city, but is only supplied for a few hours per day, to each area of the city (Sule, no date). In middle-class housing, an illusion of constant supply is created through the storage of mains water in tanks to be used at other times in the day, and supplementation by other forms of access, such as tankers and borewells, for nonpotable purposes (Button 2017). For poorer households, mains water connections are often from stand-pipes in the street, shared between several households and water must be collected in buckets whenever the taps spring to life (Anand, 2011, Graham et al., 2013). It is often women and girls who spend time collecting water and the rhythm of the stand pipe can re-order their days. Many other informal residents have no mains connection leading to a reliance on expensive water tankers or the creation of illegal connections to mains water pipes (ibid).

Crises and failures of the system are often seen as moments in which the infrastructure of a city is suddenly foregrounded (Graham and Marvin, 2001, Kaika, 2005). Domestic water supply is therefore presented as operating in an isolated 'black box' in much of the literature from the global North, and only becomes visible when it breaks down (Shove, 2003, Graham, 2006). However, it could be argued that the everyday occurrence of inadequacy and failure of Mumbai's infrastructure keeps water supply visible as an issue. In Mumbai, shortages and failures are endemic. Frank Trentmann (2009) argues that disruption is normal in most systems (and not just in the global South); and argues that the reaction to these disruptions depends on the degree to which they are accepted as normal. In Mumbai, interruptions occur often, and the infrastructure is highly differentiated and flexible as a result. Those households that do have a piped mains water connection only receive water for a few hours per day and store it in tanks as well as using other forms of supply. Thus, water is brought into homes and domesticated in different ways.

The middle classes (and elites) have the financial means to secure their clean water supply, by calling for additional water tankers, digging borewells, and now through rainwater harvesting. The promotion of 'green' infrastructure (such as rainwater harvesting) is a new way of prioritising the systems for the wealthy as those who can afford to fund additional sources can create their own water supply. Many of Mumbai's residents do not have access to formal water supplies, but self-funded decentralised supplies are now being emphasised as a solution to deficits in water infrastructure (McFarlane, 2008b). The addition of rainwater harvesting infrastructure to a building does not just help its residents, but improves water provision across the city by reducing demand, and is suggested as a solution to shortage by the municipality (Municpal Corporation of Greater Mumbai (MCGM), 2008). Rainwater harvesting and ground water recharge may also improve water quality from borewells, and reduce cracking and collapse of buildings (Sule, no date). The increasing provision of alternative technologies at the scale of individual buildings should mean that less water (and electricity and municipal solid waste) infrastructure needs to be provided centrally by the state or private companies to meet everyone's demands.

The installation of these rainwater-harvesting technologies, however, amounts to an acceptance of the reduced supply by the state, and normalises water shortage. This might be accepted by the middle classes, who can increase their resilience to shortage by installing other water sources, but it could 
actually reduce water access of the poorest residents by legitimising reduction in state water supplies for residential areas. Those people living in informal settlements are likely to be most adversely affected by the rolling back of state provision, rather than the extension of it, as well as being most vulnerable to water shortages. The management of water supplies and collection of water often adds to the double burden of women and girls in Mumbai.

\section{Rainwater harvesting as a solution to water shortages}

Green buildings also need rainwater harvesting and water recycling. Green buildings reduce costs, not just for residents but also for city level.

(Prof. Saugata Roy, Minister of State for Urban Development. Speaking at the National Conference on Green Design: Buildings and Habitats, New Delhi, 8 January 2011.)

Globally, people are seeking solutions to water insecurity, and the harvesting of rainwater offers potential in many contexts. There are many different ways to collect rainwater depending on the circumstances. In many regions of the world, water is collected from roofs of buildings, and stored in tanks either above or below ground Handia et al. (2003) look at examples in urban Zambia and Kahinda et al. (2007) discusses rainwater harvesting in the context of rural South Africa. Villages in Northern India, where water is scarce due to low rainfall, have collected rainwater in large ponds or wells for use by the community for centuries, particularly for watering crops (Pandey et al., 2003). In contrast, in dense urban areas and to monsoonal climates, like Mumbai, where water systems that recharge the ground water or aquifers are favoured. In these contexts, if rainwater is collected, it is often used for specific practices, such as watering plants or flushing toilets, and this is made possible due to the fact that these two forms of water supplies remain separate.

Rainwater harvesting offers a new source of water that could be transformative for Mumbai-dwellers with limited access to water, especially the urban poor. This substitution of water supplies can be framed as an environmental solution that could save water and alleviate stress on Mumbai's infrastructure, with the added benefit that the limited supplies from other sources are freed up to be used more abundantly for other practices. Rainwater harvesting has been compulsory since 2003 in newly constructed buildings in Mumbai, built on plots over $1000 \mathrm{~m}^{2}$ (BrihanMumbai Municipal Corporation, 2003) and in those constructed on sites over 300 $\mathrm{m}^{2}$ since 2007 (Municpal Corporation of Greater Mumbai (MCGM), 2008)Retrofits are becoming increasingly popular also, as the municipality reduces mains water supplies and promotes water saving initiatives, and this reduces reliance on mains water supplies.

In my research, a Municipal Officer working for MCGM stated:

We made that it [rainwater harvesting] is compulsory for all new buildings. But why only new buildings? Why not for the old buildings? [...] because I understand that would be a constraint of space. The new buildings have a lot of space and they follow a lot of new rules and norms, which are very different from the older norms. But still you should allow anyone to do it and it should be compulsory for everyone.

(Interview, Mumbai 20 January 2011).

All three of the case studies in my research were of retrofits to existing domestic buildings. These are becoming popular through the incentives of water security and economic gains, rather than by legislation. The officer in charge of rainwater harvesting at the BMC told me that most of the requests for information are from residents of existing buildings looking to retrofit and take control of their 
water supplies, rather than developers constructing new apartment buildings (interview, Mumbai, 10/02/2011). Thus, retrofits seem to be set to become an important, but unregulated, part of the urban environmental responses that bring additional water supplies into homes.

\section{Domestication as a concept to help understand water provision}

In my exploration of rainwater harvesting in Mumbai, I drew on the idea of domestication. The concept of 'domestication' denotes the taming and re-scaling of infrastructure to fit into the home, and has been used by several academics to explain the relationship between nature, cities and homes.

Maria Kaika (2004) uses domestication as part of her explanation of how nature is tamed and brought into the modern home. The idea of domestication draws on concepts of political power, control over nature, and the creation of comfort in the home. In particular, Maria Kaika uses the idea to conceptualise how modern homes control and sort nature. She sees domestication as bringing nature into the home and taming it (such as piped potable water), and also excluding unwanted natural elements (such as sewage or pollution).

A second view of domestication comes from Elizabeth Shove (2003). She writes about how the uptake and adoption of a new technology into the everyday practices of the home can be thought of as domestication, to create comfort. For Shove, domestication takes places when technology is '... adapted, incorporated and converted...' (55), through everyday practices in the home. Elizabeth Shove goes on to argue that, although available technology shapes human practices, the way in which technology is brought into homes and used in accordance with residents' requirements also feeds back into and changes the socio-technical system of water supply.

The idea of domestication was also taken up by a third writer, Eric Swyngedouw (2004), who researched water provision in Guayaquil, Ecuador. He sees the ability to domesticate your water and bring it into the home is an expression of social power (Swyngedouw 2004). The privatisation of responsibility for water provision changes the social contract between individual households and the city authorities. Private housing becomes a site of resource provision and control. Domestication can therefore be seen as an extension of urbanisation and the commodification of water. I found his analysis useful when looking at the ways water infrastructure is being taken into Mumbai's middleclass homes, and the effects of this on water provision not only for these households, but different categories and groups of people and for power relations in the city.

In the context of my case studies, these ideas about domestication of water supplies into the home or community were useful. I focused on the domestication of technology (Shove, 2003), water (Swyngedouw, 2004) and nature (Kaika, 2004) to consider what it means to domesticate environmental infrastructure through the use of rainwater harvesting in the apartments of Mumbai.

\section{The resident as consumer and supplier}

In most of the cases, it's the residents. Whether they have implemented it or not, it is the residents that come forward. And especially it is one resident who is aware of it and then they build up momentum in their society. And then usually we have done, I don't know how many presentations to residential housing societies. We go there and show them what is rainwater harvesting and why and how it will benefit them.

Architect and scholar (interviewed in Mumbai 13/02/2010) 
Residential buildings are an important scale at which to investigate environmental technologies and governance. Housing brings together services, both through large scale centralised infrastructures and small-scale decentralised systems, for use in a variety of practices.

\section{Apartment Building 1: Early adopters}

The first of my three case studies focused on a middle class apartment building in the northern suburbs of Mumbai. Rainwater harvesting was retrofitted several years before my visit, and was a great success. The building's co-operative secretary was engaged in raising awareness of the technology in Mumbai. They had also subsequently installed a solar water heater and photovoltaic cells to power lighting in communal areas.

Economic reasons were cited by residents for the installation of rainwater harvesting, especially in buildings that were relying heavily on tankers to reinforce their water supply before. The capital costs may be high, but the savings quickly add up. The male resident and secretary of the co-operative society at Apartment Building 1, told me:

People take these environmental technologies as a cost, but it is not a cost. It's an investment. (Interview, Mumbai, 09/01/2010)

The use of rainwater as a source of potable water is a controversial issue. Although rain can be one of the purest sources of water, the methods of collection, storage and treatment are vital to maintaining the quality. With the correct storage and/or treatment there is no reason why harvested rainwater cannot be used for all purposes (Handia et al., 2003). However, although the rainwater is likely to be cleaner and safer than some of the sources in Mumbai, it was not seen as acceptable for use as potable water by the middle classes in this particular building. The same informant told me:

One is the suspended matter is higher. The content of suspended matter, it comes from there. The second is that the bacteria count is a little higher.

(Interview, 24 January 2011).

Harvested rainwater may still be used as potable water in extreme circumstances, and/or when a special filter is in place. At Apartment Building 1 they had a series of filters, including a UV filter, in place to supply potable water in times of extreme water shortage.

Following on from the success of providing their own water supply, some residents are looking to supply other services in their own buildings. This domestication of services sees buildings and homes becoming both the producers and consumers of resources: the ultimate in privatisation. Several buildings in Mumbai now have solar-water heating and/or photovoltaic panels to supply some of the residents' energy needs. In effect, they have begun to run their own private energy companies to govern their own resource supply. This changes the boundaries and relationships between the home, the buildings and the city, and there is a shift in power dynamics alongside this growing resilience and resource security.

Apartment building 2: Learning from example and thinking about power relations between servants and employers

The residents of Building 2 were advised to adopt rainwater harvesting by the residents of Building 1 . In addition to showing learning by example, I will focus on them here to discuss the issues of power 
and class relations that came up in the research as participants reflected on the issues around water supplies faced by their domestic servants.

The gardens at Apartment Building 2 showed the difference that harvesting rainwater can make. A female resident and head of household explained how the retrofitted rainwater harvesting system has affected consumption and gardening practices. A woman resident of Apartment Building 2 stated:

Where I used to tell the gardener - 'please, today don't water, water only once in three days, or once in five days' - now he does it merrily every day and he's happy.

(Interview, Mumbai, 24 January 2011).

In the eleven months between two visits to Building 2, the gardens at this property became visibly more extensive and verdant. This greenery has the added benefit of cooling the microclimate around the building, making it more pleasant in a hot, humid area like Mumbai. Site visit observations confirmed that it is male servants who perform the watering of the gardens, either a dedicated gardener in large buildings and townships, or as an extra responsibility of the watchman as observed in smaller apartment buildings.

The number and extent of servant employment in India is high, and hiring servants can be used as proof of middle class status and provide the convenience and lifestyle desired (Qayum and Ray, 2011). This outsourcing of care work within the household means that it may be the servants who are most aware and in control of resources, and they could be more aware of environmental impacts on water supply in their own home lives.

The labour is so cheap you get used to all this, you know, it's so comfortable. We have a couple of people working at home and everything is just set the way you want it and you don't have to do anything.

Property Developer (interview, Mumbai, 16/12/2009)

In Mumbai many of these servants live in informal settlements, with limited access to water and sanitation (Gandy, 2008, McFarlane, 2008a). Severe water shortages are impacting on life in these settlements, and middle class residents are aware of this, and the fact that the resources and amenities they take for granted are not available where their servants live. The same woman resident quoted above described the problems that her maids report from the slums in which they live:

All our maids come from there [a nearby slum], and they are always complaining. Last three days they just didn't have any water. Like they just had water for barely two hours and they just had a queue for one tap and a whole lot of... so she said "all that we managed to gather was drinking water" so it's just no bathing, no other. Just bare essentials. So it is a huge problem.

(Interview, Mumbai, 24 January 2011).

Some of the male servants may reside underneath the apartment building, in-between the cars parked in the raised plinth or in the stairwells in-between the cars parked in the raised plinth or in the stairwells but again have very different access to water.

This analysis has obvious gendered implications since women are the primary consumers and users of water in their role as family carers, and this division of labour is reflected in the gendered roles of servants. The female domestic workers contracted to perform care work are tasked with ensuring their employers have a ready supply of water in their homes. Gender therefore intersects with class. 
Rainwater harvesting did have a measure of positive impact on servants' lives. Firstly, servants have access to clean water at work, even when there is a water shortage at home, and they may be able to access this for personal use. Water shortages at home are rarely reflected in a maid's work, but demonstrate the gendered nature of water practices and of the space of the home. Secondly, rainwater supplies may actually reduce the drudgery of collecting water from municipal supplies or supervising tanker deliveries, when middle-class homes experience water shortages.

...we use this water for 24 hours for flushing and all. Floor washing. We can get more water. 24 hours. Male resident of a middle-class Apartment Building in Bandra West (interview, Mumbai 24/01/2011).

Thirdly, rainwater can be used for a variety of tasks that are easier with plentiful water. Floors are washed by maids and cars are cleaned by watchmen every day, due to the very dusty conditions in Mumbai. Availability of additional water can make it easier to perform cleaning tasks. These are normalised practices that can increase water consumption (Shove, 2003). However, the practice of floor washing can be carried out using a small amount of water.

I use two buckets of water to clean the floors in the entire apartment

Daily maid (interview, Mumbai, 08/02/2011)

In that building rainwater is used for cleaning inside the homes, particularly the floors, and for cleaning the offices of the cooperative management. Thus reducing consumption of the mains water supply by changing sources, rather than practices. The power to choose the source and supply of drinking water and to ensure the quality of water for your family is a privilege not open to everyone (Gandy, 2006). The everyday water practices using rainwater harvesting illustrate the power dynamics of the Indian middle class home. They highlight the injustices of water provision by who performs a specific task and who has access to which water sources for their personal use, as shown by the reluctance of middle classes to consume rainwater, but allowing servants to do so. Despite middle-class fears about using rainwater as potable water, there was evidence of the water being made available for servants to drink and cook with: an example of how power relations are seen in play - and reinforced - through obvious differentiation around resource use. This also reveals some of the justice implications of water practices.

\section{Informal Settlement: Domesticating the slum and the water supply}

My third example here concerns the use of a rainwater harvesting system in an informal settlement to flush the toilets of a communal toilet block.

I discovered only one rainwater harvesting system in an informal settlement, and conducted interviews and made observations there. The rainwater harvesting scheme is at an informal settlement in North Mumbai and was undertaken by a community-based origination called Triratna Prerana Mandal (TPM) (Alfred Herrhausen Gesellschaft). Rainwater is collected from the outdoor play area and the roof of the community centre that TPM constructed. This water is now used to flush the public toilets at the centre. This shows the potential for much needed rainwater harvesting schemes in informal settlements, but there may not be space. TPM were also considering installing photovoltaic panels to power lighting and computers. This leads to the domestication of shared space, as everyday practices are undertaken at the community centre, it becomes parts of people's homes

The residents in the first and second examples, above, were able to secure their water services in the wider context of a secure lifestyle, but poorer citizens do not have the capacity to do this by retrofitting rainwater harvesting systems. One major issue is space: the roofs and grounds are not individually 
large enough to collect rainwater for use by the residents. Space is also needed for storage or recharge into an aquifer or well. Rainwater harvesting can save recurring expenditure on water, but it requires an investment of capital. In addition, lack of security of tenure in informal settlements reduces the commitment to improvements. The MCGM favours redevelopment and rehabilitation, rather than upgrading and investment, in informal settlements.

There is also the issue of funding schemes and of political will. In Mumbai, the municipality is reluctant to supply informal settlements with infrastructure as this could legitimise the area (Graham et al.). Decentralised systems could help bridge the infrastructure deficit, but the current focus for the city authorities is, rather, on promoting middle-class responses that are self-funded (Button, 2017). Rainwater harvesting as a solution for middle-classes normalises uneven water distribution. Lack of pressure from the middle classes to supply water lets the state 'off the hook', allowing it to roll back provision, and abandon aspirations for equitable water provision for all citizens of Mumbai.

\section{Beyond privatisation}

Privatization of water is contested politically and the privatisation of water supplies has been undertaken across the world to varying degrees and in different ways. In India, the water supply has not been privatised in a formal way, leaving the ultimate responsibility for water provision to the state. However, in practice, some parts of water supply have been taken on by private endeavours; either for profit - as in the example of the water tankers of the 'Water Mafia' [1] - or to build personal resilience to fluctuations in supply, as in the example of the rainwater harvesting discussed in this paper, blurring state and non-state boundaries (Bulkeley and Schroeder, 2011).

The rolling back of mains water supply by the municipality and the encouragement to save water and install rainwater harvesting technology has led individual citizens to govern their own water supplies. This shifts governance debates from the interactions of institutions, to a focus on individuals within buildings. Residents now have more control over their water supplies, leading to more water availability at lower costs.

It could be suggested that this governing and supply of water, and other services, at the building level by private householders could reduce the amount of corruption experienced around water supply. Decentralisation and involvement of stakeholders in governance of resources, including water, has been seen to achieve this in other Indian states where moving from regional local government water governance had increased corruption levels (Asthana, 2008). However, the current situation in Mumbai could be characterised, using Karen Bakker's ideas (2010), as going 'beyond privatisation' of water supply, in the sense of the residents and civil society taking responsibility for securing water supplies. When the state fails to provide services, some residents fill the gaps in provision by other means, such as harvesting rainwater to deal with water shortages.

Active interaction between providers and users of environmental services is important, and good links can lead to accountability in decision-making (Baud and Dhanalakshmi, 2007). But what happens when the providers and users of those environmental services are the same people and places? In the case of Mumbai, privatisation of water supply through rainwater harvesting has occurred at the scale of the individual building, making suppliers and consumers the same actors. This domestication gives residents greater control over their supply through this extreme form of privatisation down to the micro/building scale. The governed and the governors have, in effect, become one and the same as the water supplies are domesticated.

Decentralised systems could help bridge the infrastructure deficit by freeing-up more of the municipal mains supply for use by other citizens. However, the potential to save municipal supplies for those 
who cannot afford rainwater systems does not appear to be realised; lack of a shared interest in saving water means some middle-class residents opt to use rainwater harvesting systems and water saving technology for uses deemed by them to be essential, but which people in poverty would not recognise as such. The availability of rainwater through harvesting has been found to increase water consumption of middle class residents who can now afford to use water for other practices that were restricted before (such as watering gardens and frequently washing cars) (Button, 2014).

Linking development commitments to providing water to all with the realities of today's rapidly growing cities in global South contexts involves adopting pragmatic and efficient solutions. It should not matter whether infrastructure consists of monolithic centralised systems or dispersed decentralised systems, as long as it is well-built, well-maintained, and provides resources to all citizens. Rainwater harvesting could be a solution if education and funding streams made it a technology available to all, and this will be a great missed opportunity if it continues to only be accessible to the middle classes.

\section{Conclusions: domesticating infrastructure governance}

There is an important difference between more people getting access to some water, and some people getting access to more water. The domestication of water supplies has produced middle classes that are becoming increasingly resilient to water (and energy) shortage and to some aspects of climate change. Yet the rolling back of state responsibility for water supply and promotion of middle class responses to resource shortage has several consequences for the future of services in Mumbai.

It shifts the responsibility for governing water resources to the residents, reconfiguring their role to become both consumer and supplier. Housing is being re-cast as a provider of services, primarily of water through rainwater harvesting interventions. The state is reinforcing this domestication, with middle-class residents as producers and consumers of decentralised 'green' resources, through rainwater harvesting legislation and other initiatives.

Yet as I have argued, this domestication of water supplies, and their governance, is allowing the state to redefine its role as service provider, and roll back its responsibility for universal provision. My research suggests that the middle-class residents of Mumbai are potentially gaining more control, as contrasted to more negative implications for the domestic workers whom they employ, and for the poorer residents of the city who are not able to afford rainwater-harvesting technologies.

The prioritisation of rainwater harvesting as a response to both shortage and to the environmental issues facing Mumbai is putting the needs and wants of the middle classes before those of the poor majority, who cannot afford to install a rainwater harvesting system. Private middle class residents are working to secure their water and energy supplies by retrofitting rainwater harvesting systems. This decentralisation of resources redefines residential buildings' relationship with the city and the boundaries of infrastructure, and gives residents more power over their water. Yet this particular form of decentralisation of water provision has class and gendered implications, creating particular issues for informal slum dwellers, and servants in their roles as paid domestic carers for their employers. Women have gendered responsibility for water use in domestic settings and are the least likely to participate in decision-making on water supply and infrastructure design, maintenance and use.

In conclusion, this emphasis on middle class responses to water shortage and environmental concerns has justice implications in a city where 60 per cent of the population live in informal settlements with reduced water access, and lower resilience. Because the middle classes are able to evolve ways of coping with the shortage of municipal water supplies, they accept the roll-back of state provision. As the middle classes collect and supply their own water they form a new type of localised privatisation, 
which feeds back into legislation and shifts power, governances and changes the relationship with the city.

Cat. Button is Lecturer of Global Urbanisms in the School of Architecture Planning and Landscape, deputy chair of NU Women and a member of the Global Urban Research Unit at Newcastle University, UK. Her research focusses on how people and communities cope with having too little (or too much) water.

Postal Address: SAPL, Claremont Tower, Newcastle University, Newcastle, UK NE1 7RU

Email Address: cat.button@ncl.ac.uk

\section{Endnotes}

[1] The Water Mafia is a collection of people and organisations who control the black market in water. They make money by selling water illegally and accepting bribes. They are also known to use intimidation methods to secure their market (see Graham et al., 2013).

\section{References}

Alfred Herrhausen Gesellschaft (2009) Triratna Prerana Mandal (TPM).

Anand, N. (2011) PRESSURE: The PoliTechnics of Water Supply in Mumbai. Cultural Anthropology 26, 542-64.

Asthana, A.N. (2008) Decentalisation and Corruption: evidence from drinking water sector. Public Administration and Development 28, 181-9.

Bakker, K. (2010) Privatizing Water: Governance Failure and the World's Urban Water Crisis. Cornell University Press, New York.

Baud, I. and R. Dhanalakshmi (2007) Governance in urban environmental management: Comparing accountability and performance in multi-stakeholder arrangements in South India. Cities 24, 133-47.

BrihanMumbai Municipal Corporation (2003) Water conservation \& rainwater harvesting for BrihanMumbai. BMC, Mumbai.

Bulkeley, H. and M.M. Betsill (2003) Cities and Climate Change: Urban sustainabiility and global environmental governance. Routledge, London.

Bulkeley, H. and H. Schroeder (2011) Beyond state/non-state divided: Global cities and the governing of climate change. European Journal of Internaional Relations, 1-24.

Button, C. (2014) Domesticating Infrastructure: Mumbai's middle class housing and rainwater harvesting. Department of Geography, Durham University, Durham.

Button, C. (2017) The co-production of a constant water supply in Mumbai's middle-class apartments. Urban Research \& Practice 10, 102-19.

Gandy, M. (2006) Water, Sanitation and the Modern City: Colonial and Post-colonial Experiences in Lagos and Mumbai. Human Development Report 2006, UNDP.

Gandy, M. (2008) Landscapes of disaster: water, modernity, and urban fragmentation in Mumbai. Environment and Planning A 40, 108-30. 
Graham, S. (2006) Urban metabolism as target: Contempory war as forced demodernisation. In N. Heynen, M. Kaika and E. Swyngedouw (eds.), In the Nature of Cities: Urban Political Ecology and the Politics of Urban Metabolism, Routledge, Oxon, 245-65.

Graham, S., R. Desai and C. McFarlane (2013) Water Wars in Mumbai. Public Culture 25, 115-41.

Graham, S. and S. Marvin (2001) Splintering Urbanism: networked infrastructures, technological mobilities and the urban condition. Routledge, London.

Handia, L., J.M. Tembo and C. Mwiindwa (2003) Potential of rainwater harvesting in urban Zambia. Physics and Chemistry of the Earth 28, 893-6.

Kahinda, J.-M.M., A.E. Taigbenu and J.R. Boroto (2007) Domestic rainwater harvesting to improve water supply in rural South Africa. Physics and Chemistry of the Earth 32, 1050-7.

Kaika, M. (2004) Interrogating the Geographies of the Familiar: Domesticating Nature and Constructing the Autonomy of the Modern Home. International Journal of Urban and Regional Research 28, 265-86.

Kaika, M. (2005) City of Flows: Modernity, Nature, and the City. Routledge, Oxon.

McFarlane, C. (2008a) Sanitation in Mumbai's informal settlements: state, 'slum', and infrastructure. Environment and Planning A 40, 88-107.

McFarlane, C. (2008b) Urban Shadows: Materiality, the 'Southern City' and Urban Theory. Geography Compass 2, 340-58.

Municpal Corporation of Greater Mumbai (MCGM) (2008) Brihanmumbai Mahanagarpulika: Rain Water Harvesting. In Rain Water Harvesting (ed.), MCGM, Mumbai.

Pandey, D.N., A.K. Gupta and D.M. Anderson (2003) Rainwater harvesting as an adaptation to climate change. CURRENT SCIENCE 85, 46-59.

Qayum, S. and R. Ray (2011) The Middle Classes at Home. In A. Baviskar and R. Ray (eds.), Elite and Everyman: The cultural politics of the Indian middle class, Routledge, New Delhi, 246-70.

Shove, E. (2003) Comfort, Cleanliness and Convenience. The Social Organization of Normality. Berg, Oxford.

Srivastava, R. and M. Echanove (2014) 'Slum' is a loaded term. They are homegrown neighbourhoods. The Guardian.

Sule, S. (no date) Mumbai's water supply. In N. Mukherjee (ed.), Understanding our civic issues, Bombay Community Public Trust, Mumbai.

Swyngedouw, E. (2004) Social Power and the Urbanization of Water: Flows of Power. Oxford University Press, Oxford.

Trentmann, F. (2009) Distribution is Normal: Blackouts, Breakdowns and the Elasticity of Everyday Life. In E. Shove, F. Trentmann and R. Wilk (eds.), Time, Consumption and Everyday Life: Practice, Materiality and Culture, Berg, Oxford, 67-84.

Zérah, M.-H. (2008) Splintering urbanism in Mumbai: Contrasting trends in a multilayered society. Geoforum 39, 1922-32. 